\title{
Terapi Herbal Sari Mentimun untuk Menurunkan Tekanan Darah pada Penderita Hipertensi
}

\author{
Nur Sefa Arief Hermawan ${ }^{\left(1^{*}\right)}$, Nana Novariana ${ }^{(2)}$ \\ ${ }^{1,2}$ Program Studi Kesehatan Masyarakat STIKES Mitra Lampung Bandar Lampung \\ ${ }^{\left({ }^{*}\right)}$ sefa@umitra.ac.id $;{ }^{(2)} \underline{\text { nana@umitra.ac.id }}$
}

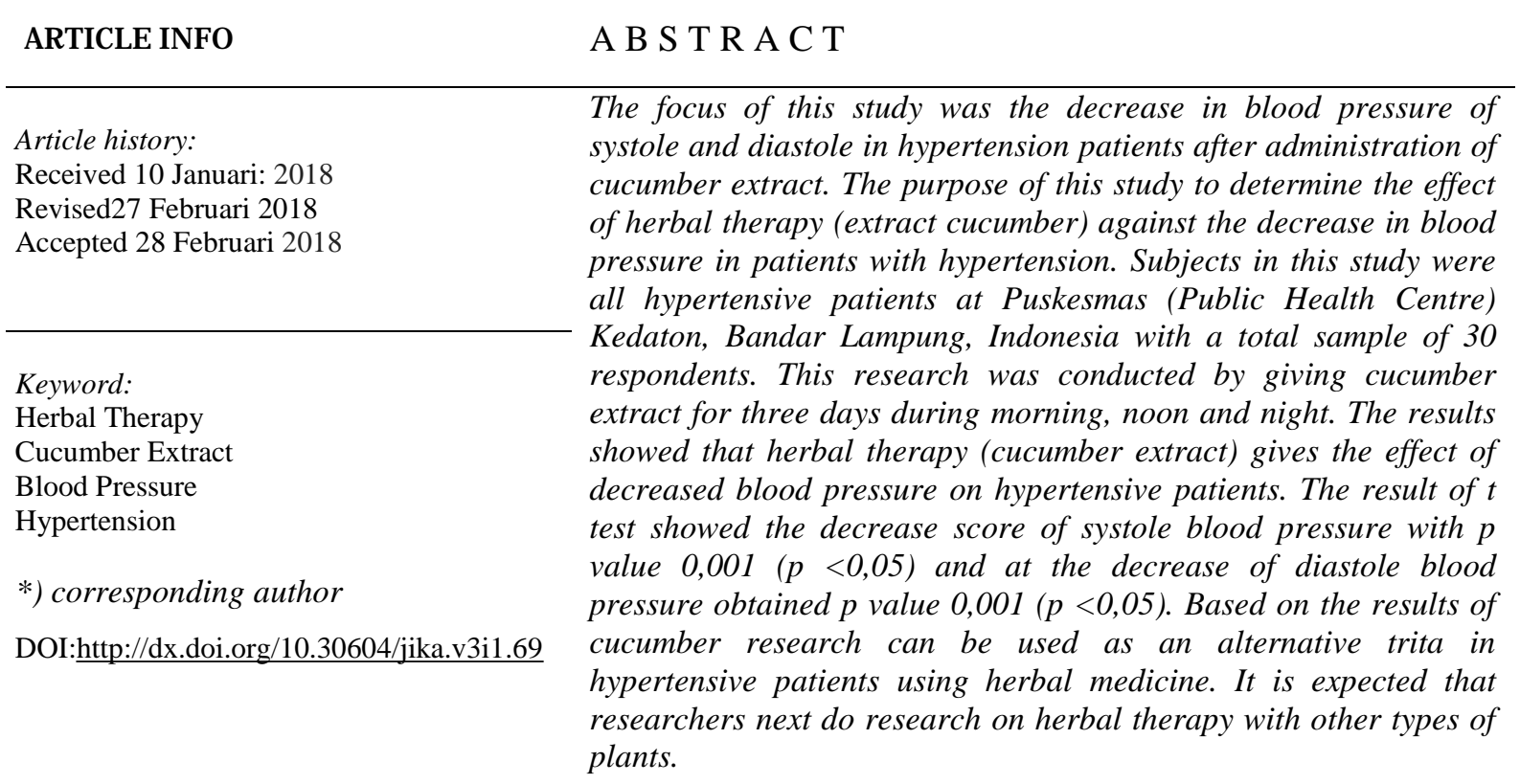

Copyright @ 2018 , Jurnal Aisyah: Jurnal Ilmu Kesehatan. All rights reserved.

\section{PENDAHULUAN}

Penyakit darah tinggi atau hipertensi merupakan salah satu penyakit degeneratif dan dapat mengakibatkan risiko kematian. Pemyakit ini menjadi semakin besar risikonya jika tekanan darah tidak terkontrol dengan benar, hipertensi sering dijuluki sebagai silent killer. Julukan ini, diibaratkan sebagai bom waktu yang pada awalnya tidak memberikan gejala-gejala yang pasti, sehingga penderitanya tidak memikirkannya secara serius karena tidak terdapat tanda - tanda yang muncul sebagai peringatan akan adanya kerusakan organ yang lebih luas (Suprapto, 2014).

Tercatat bahwa sekitar 972 juta jiwa pada tahun 2012 di seluruh dunia menderita tekanan darah dan negara berkembang dunia menyumbang hampir dua kali lipat dibandingkan dengan negara maju (sekitar 639 juta jiwa di negara berkembang dan sekitar 333 juta jiwa di Negara maju) 
sehingga prevalensi kejadian tekanan darah di seluruh dunia adalah sekitar 26,4 persen dari seluruh populasi dunia. Selain itu, diprediksi juga bahwa pada tahun 2025, kejadian tekanan darah akan meningkat menjadi 60 persen dari seluruh populasi, yaitu sekitar 1,56 milliar jiwa (WHO, 2012).

Prevalensi kejadian hipertensi dengan Tekanan Darah > 130/100 mmHg dengan usia > 30 Tahun pada tahun 2010 mencapai 26.130 orang, pada tahun 2011 mencapai 26.475 orang dan pada tahun 2012 mengalami peningkatan yang mempengaruhi sehingga mencapai 27.912 orang, dengan data tersebut penyakit hipertensi menduduki peringkat ke 5 dari 10 besar penyakit yang ada Di Provinsi Lampung (Dinkes.Provinsi Lampung, 2012).

Dari hasil observasi pada masyarakat Kecamatan Kedaton Bandar Lampung didapatkan bahwa dominan masyarakat tersebut menyukai buah atau sayuran mentimun ini yang sering dikonsumsi dengan makanan pokok mereka yaitu nasi yang dijadikan sebagai lalapan bagi masyarakat setempat.

Mentimun juga memiliki beberapa kandungan seperti, protein, lemak, karbohidrat, kalium, zat besi, magnesium, fosfor, vitamin A, vitamin B1, vitamin B2, vitamin C. Jadi mentimun ini layak disebut tanaman herbal.

Berdasarkan data dari Puskesmas Kedaton Bandar Lampung didapatkan bahwa penderita hipertensi mengalami kenaikan yang tinggi yaitu pada tahun 2014 penderita hipertensi mencapai angka 865 orang dan pada tahun 2016 mencapai angka 977 orang (Data Profil Puskesmas Kedaton, 2016).

Penelitian yang dilakukan oleh Agnes Silvina Marbun, Remicha Juwita Marpaung, Endriani Sari Samosir dalam penelitian Pengaruh Sari Mentimun (Cucumis Sativus Linn) Terhadap Tekanan Darah Pada Penderita Hipertensi Di
Lingkungan XII Kelurahan Dwikora Kecamatan Medan Helvetia Tahun 2012 dengan hasil penelitian menggunakan quasy eksperimen design dengan rancangan "one group pre - post test" diambil menggunakan teknik purposive sampling menggunakan Uji Paired t-tes dengan tingkat kepercayaan 95 persen pada nilai $\alpha$ $=<0,005$. Dengan Uji statistik tekanan darah sistole dan diastole sebelum diberikan sari mentimun $152.31 \mathrm{mmHg} / 104.23$ $\mathrm{mmHg}$ dan setelah diberikan sari mentimun $134.62 \mathrm{mmHg} / 94.62 \mathrm{mmHg}$.

Menurut penelitian Lailatul Muniroh, Bambang Wirjatmadi, Kuntoro (2007) tentang Pengaruh Pemberian Jus Buah Belimbing dan Mentimun terhadap Penurunan Tekanan Darah Sistolik dan Diastolik Penderita Hipertensirawat jalan Puskesmas Grati Kabupaten Pasuruan , desain penelitian adalah Randomized Pretest-Posttest Control Groupp, menyebutkan tidak ada beda tekanan darah sistolik awal $(\mathrm{p}=0,528)$ dan diastolik awal ( $\mathrm{p}=0,184)$ antara kelompok perlakuan dan kelompok kontrol.

Salah satu, terapi pengobatan untuk penyakit hipertensi adalah pemanfaatan sari mentimun. Kandungan yang terdapat dalam mentimun seperti mineral di mentimun yaitu potassium, magnesium dan fospor yang dapat mengobati hipertensi. Didalam mentimun yang bersifat diuretic dan kandungan air yang tinggi berfungsi sebagai penurunan tekanan darah tinggi (Yekti, 2014). Mentimun atau timun merupakan salah satu sayuran yang dapat dikonsumsi baik dalam bentuk segar maupun olahan seperti acar dan asinan. Mentimun atau timun dapat membantu membersihkan pencernaan, mendinginkan suhu tubuh dan menyehatkan tubuh. Mentimun atau timun juga berperan pada jaringan konektif seperti intraseluler, otot, tendon, ligament, kartilago dan tulang. Mentimun selain mengandung potassium, magnesium dan fospor mentimun atau timun memiliki kandungan gizi yang cukup 
baik karena merupakan sumber mineral dan vitamin.

Berdasarkan penelitian yang telah di uji cobakan, maka peneliti tertarik untuk melakukan penelitian pemberian sari mentimun pada pasien hipertensi dan membuktikan apakan ada pengaruh perlakuan terhadap tekanan darah pasien sebelum dan sesudah pemberian sari mentimun. Penelitian ini dimaksudkan agar penderita hipertensi dapat mengatasi penyakitnya tanpa menggunakan obat anti hipertensi. Penelitian dilakukan dengan tujuan untuk mengetahui pengaruh terapi herbal (sari mentimun) terhadap penurunan tekanan darah pada penderita hipertensi di Puskesmas Kedaton Bandar Lampung.

\section{METODE}

Jenis penelitian ini, merupakan penelitian survey analitik dengan rancangan penelitian quasi experiment digunakan untuk mengetahui hasil dari pretest dan posttest pada penderita hipertensi dengan penurunan tekanan darah sesudah dan sebelum mengkonsumsi sari mentimun pada kelompok responden yang sama. Dengan gambaran desain penelitan menggunkan kelompok intervensi dan kelompok kontrol, skema sebagai berikut:

Kelompok Intervensi

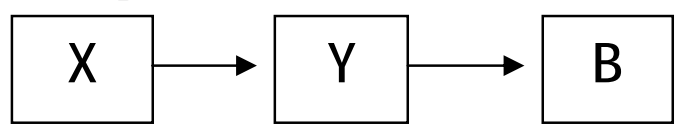

Kelompok Kontrol

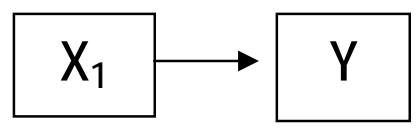

Keterangan:

$\mathrm{X}$ : Kelompok Intervensi

Y : Obat Farmakologi

$\mathrm{X}_{1}$ : Kelompok control

B : Terapi Herbal (sari mentimun)

\section{Prosedur pembuatan sari mentimun}

Bahan yang digunakan adalah dua buah atau sayuran mentimun segar. Prosedur pembuatan sari mentimun yaitu dengan mencuci bersih buah atau sayuran mentimun kemudian buang kulitnya dan hancurkan buah mentimun menggunkan penghancur makanan kemudian saring mentimun dan ambil sarinya, minum sari mentimun sebanyak 2 - 3 kali dalam sehari yaitu pagi, siang dan malam hari.

Populasi pada penelitian ini adalah penderita hipertensi yang berobat di Puskesmas Kedaton Bandar Lampung pada bulan Mei dan Juni 2016 yang mempunyai kesempatan yang sama pada penelitian ini untuk dipilih dan bersedia dijadikan sampel.

Sampel dalam penelitian ini yaitu semua penderita hipertensi yang berobat di Puskesmas Kedaton Bandar Lampung pada saat penelitian berlangsung penggambilan sampel pada penelitian ini menggunakan accidental sampling yaitu dilakukan dengan cara mengambil masalah atau responden yang saat penelitian berlangsung.

Adapun kriteria inklusi pada penelitian ini yaitu: 1) Bersedia menjadi responden; Bersedia mengkonsumsi sari mentimun; 3) Mengerti bahasa Indonesia; 4) Kooperatif

\section{Teknik Pengumpulan Data Penelitian}

Pada penelitian ini, pengumpulan data instrument dilakukan dengan pengukuran tekanan darah menggunakan tensi meter untuk mengetahui nilai tekanan darah pada penderita hipertensi di Puskesmas Kedaton Bandar Lampung Tahun 2016. Kemudian pengobatan herbal dengan mengkonsumsi sari mentimun diberikan dan diajurkan pada penderita hipertensi sebanyak $2-3$ kali dalam sehari.

Teknik Pengumpulan Data dilakukan dengan cara sebagai berikut: 1) Memberikan penjelasan kepada responden dengan singkat dan jelas; 2) Memberikan surat persetujuan untuk menjadi responden; 
3) Melakukan pengukuran tekanan darah menggunakan alat tensi meter pada responden sebelum dan sesudah mengkonsumsi sari mentimun; 4) Menganjurkan kepada responden untuk tetap mengkonsumsi sari mentimun sehari sebanyak 3 kali yaitu pagi, siang dan malam; 5) Menulis semua hasil pada lembar observasi pada saat penelitian berlangsung.
Analisa data dilakukan dengan menggunkana komputerisasi, data dianalisa dengan univariat dan bivariat menggunkan Uji statistic yaitu Uji t dependent telah di uji normalitas yang didapat nilai skewness normal. Digunakan untuk mengetahui perbedaan nilai penurunan tekanan darah pada sampel yang diberikan sari mentimun dan yang tidak diberikan sari mentimun.

\section{HASIL DAN PEMBAHASAN}

Tabel 1. Penurunan Tekanan Darah Sistole Sebelum dan Sesudah Diberikan Sari Mentimun.

\begin{tabular}{lccccl}
\hline Tekanan Sistole & Mean & SD & Min & Maks & 95\% CI \\
\hline Setelah terapi & 9.33 & 6.915 & 0 & 20 & $\begin{array}{l}5.505 \\
13.161\end{array}$ \\
\hline Sebelum terapi & 6.67 & 6.065 & 0 & 20 & $\begin{array}{l}2.839 \\
10.495\end{array}$ \\
\hline
\end{tabular}

Berdasarkan tabel 1, terdapat nilai rata rata penurunan tekanan sistolik pada responden setelah diberikan sari mentimun adalah $9.33 \mathrm{mmHg}$ (95 persen CI: 5.505 13.161), dengan standar deviasi 6.915 $\mathrm{mmHg}$ dan penurunan terendah adalah 0 $\mathrm{mmHg}$ dan tertinggi $20 \mathrm{mmHg}$. Dari hasil estimasi interval dapat disimpulkan bahwa 95 persen diyakini nilai rata - rata penurunan tekanan sistolik pada penderita hipertensi setelah diberikan sari mentimun antara $5.505 \mathrm{mmHg}$ sampai $13.161 \mathrm{mmHg}$.
Nilai rata - rata penurunan tekanan diastole pada responden setelah diberikan sari mentimun adalah $6.67 \mathrm{mmHg}$ (95 persen CI: 2.839 - 10.495), dengan standar deviasi $6.065 \mathrm{mmHg}$ dan penurunan terendah adalah $0 \mathrm{mmHg}$ dan tertinggi $20 \mathrm{mmHg}$. Dari hasil estimasi interval dapat disimpulkan bahwa 95 persen diyakini nilai rata - rata penurunan tekanan diastole pada penderita hipertensi setelah diberikan sari mentimun antara $2.839 \mathrm{mmHg}$ sampai $10.495 \mathrm{mmHg}$.

Tabel 2. Hasil Uji T test Dependent Berdasarkan Hasil Pengukuran Tekanan Darah Sebelum dan Setelah Diberikan Sari Mentimun

\begin{tabular}{lcccccc}
\hline & Sari Mentimun & N & Mean & SD & SE & p value \\
\hline $\begin{array}{lccccc}\text { Penurunan } \\
\text { Sistole }\end{array}$ & Diberikan & 15 & 14.00 & 5.071 & 1.309 & \multirow{2}{*}{0.001} \\
\cline { 2 - 5 } & Tidak diberikan & 15 & 4.67 & 5.164 & 1.333 & \\
\hline $\begin{array}{l}\text { Penurunan } \\
\text { Diastole }\end{array}$ & Diberikan & 15 & 10.00 & 5.345 & 1.380 & 0.01 \\
\cline { 2 - 5 } & Tidak diberikan & 15 & 3.33 & 4.880 & 1.260 & \\
\hline
\end{tabular}

Berdasarkan tabel 2 diketahui bahwa ratarata penurunan sistole pada responden yang diberikan sari mentimun adalah 14,00 $\mathrm{mmHg}$ dengan standar deviasi $5.071 \mathrm{mmHg}$ sementara yang tidakdiberikan sari mentimun adalah $4.67 \mathrm{mmHg}$ dengan standar deviasi $5.164 \mathrm{mmHg}$. Didapat juga nilai rata - rata penurunan diastole pada responden yang diberikan sari mentimun adalah $10,00 \mathrm{mmHg}$ standar deviasi 5.345 
mmHg dan yang tidak diberikan sari mentimun adalah $3,33 \mathrm{mmHg}$ dengan standar deviasi $4.880 \mathrm{mmHg}$. Hasil uji statistik diperoleh data bahwa $\mathrm{p}$ value untuk sistole adalah $0,001(\mathrm{p}<0,05)$ yang berarti terdapat pengaruh sari mentimun terhadap penurunan tekanan darah pada penderita hipertensi kemudian pada penurunan diastole diperoleh $\mathrm{p}$ value $0,01(\mathrm{p}<0,05)$ yang artinya ada pengaruh terhadap penurunan tekanan darah pada penderita hipertensi setelah diberikan sari mentimun.

\section{Tekanan Darah Sistole Responden Sebelum dan Sesudah Diberikan Sari Mentimun}

Berdasarkan data yang diperoleh dari 30 orang responden didapatkan bahwa terdapat nilai rata - rata penurunan tekanan sistolik pada responden setelah diberikan sari mentimun adalah $9.33 \mathrm{mmHg}$ dengan standar deviasi $6.915 \mathrm{mmHg}$.

Hal ini memberikan penjelasan bahwa pada pasien penderita tekanan darah di Puskesmas Kedaton Bandar Lampung Tahun 2016 sangat membutuhkan penatalaksanaan yang lebih mengarah kepada obat - obatan non farmakologis seperti pada terapi herbal khususnya sari mentimun dalam pengobatan penyakit hipertensi selain dengan menggunakan obat farmakologis yang bisa diberikan dipuskesmas sebelumnya.

\section{Tekanan Darah Diastole Responden Sebelum dan Sesudah Diberikan Sari Mentimun}

Berdasarkan data yang juga diperoleh dari 30 responden didapatkan nilai rata - rata penurunan tekanan diastole pada responden setelah diberikan sari mentimun adalah 6.67 $\mathrm{mmHg}$ dengan standar deviasi 6.065 $\mathrm{mmHg}$.

Berdasarkan kesimpulan tersebut menunjukkan bahwa terapi herbal sari mentimun memberikan pengaruh terhadap penurunan tekanan darah pada pasien hipertensi yang terjadi pada penurunan tekanan sistole dan juga pada penurunan diastolenya. Hal ini disebabkan karena mentimun memiliki kandungan seperti potassium, magnesium dan fospor yang dapat pengobati hipertensi. Mentimun juga memiliki kandungan uretic dan kandungan airnya yang juga dapat penurunkan tekanan darah pada penderita hipertensi. Mentimun merupakan salah satu sayuran yang dapat dikonsumsi baik dalam bentuk segar maupun olahan seperti acar dan asinan atau digunakan juga sebagai pengobatan herbal.

Mentimun juga dapat membantu membersihkan pencernaan, mendinginkan suhu badan dan menyehatkan kulit. Kandungan - kandungan pada buah mentimun ini yang dapat menyebabkan penurunan tekanan darah pada penderita hipertensi.

\section{Pengaruh Sari Mentimun Terhadap Penurunan Tekanan Darah Pada Penderita Hipertensi}

Dari hasil yang didapatkan pada pasien hipertensi di Puskesmas Kedaton Bandar Lampung Tahun 2016 bahwa rata - rata nilai sistole pada penderita hipertensi yang diberikan sari mentimun yaitu $14.00 \mathrm{mmHg}$ dengan standar deviasi $5.017 \mathrm{mmHg}$ dan pada penderita yang tidak diberikan sari mentimun yaitu $4.67 \mathrm{mmHg}$ dengan standar deviasi $5.164 \mathrm{mmHg}$ sedangkan nilai rata - rata diastole pada penderita hipertensi yang diberikan sari mentimun yaitu $10.00 \mathrm{mmHg}$ dengan standar deviasi $5.345 \mathrm{mmHg}$ dan juga nilai rat - rata diastole yang tidak diberikan sari mentimun yaitu $3.33 \mathrm{mmHg}$ dengan standar deviasi $4.880 \mathrm{mmHg}$. Hasil uji $\mathrm{t}$ dependent didapatkan nilai $\mathrm{p}$ value untuk sistole adalah $0,001(\mathrm{p}<0,05)$ yang berarti terdapat pengaruh sari mentimun terhadap penurunan tekanan darah pada penderita hipertensi sedangkan pada diastole diperoleh $p$ value $0,01(p<0,05)$ yang artinya ada pengaruh terhadap penurunan tekanan darah pada penderita hipertensi setelah diberikan sari mentimun. Jadi dapat dikatakan bahwa sari mentimun berpengaruh pada penurunan tekanan darah tinggi pada penderita hipertensi. 
Berdasarkan kesimpulan diatas menerangkan bahwa terapi herbal dalam hal ini sari mentimun memberikan pengaruh terhadap penurunan tekanan darah pada penderita hipertensi dengan nilai penurunan pada sistole dan nilai diastole. Hal ini disebabkan karena kandungan mentimun yang bersifat uretik yang bisa membuat penurunan pada tekanan darah. Dengan demikian penelitian ini memberikan titik terang pada peneliti lebih lanjut, bila kita melihat hasil pengaruh dari terapi herbal sari mentimun terhadap penurunan tekanan darah pada pasien hipertensi dan diharapkan hasil penelitian ini bisa menjadi reverensi untuk peneliti selanjutnya.

Mentimun selain mengandung potassium, magnesium dan fospor mentimun atau timun memiliki kandungan gizi yang cukup baik karena merupakan sumber mineral dan vitamin. Mentimun atau timun memiliki beberapa kandungan seperti, protein, lemak, karbohidrat, kalium, zat besi, magnesium, fosfor, vitamin A, vitamin B1, vitamin B2, vitamin C. Dengan demikian mentimun ini layak disebut tanaman herbal.

Dengan adanya penatalaksaan terapi herbal ini khususnya pemanfaatan sari mentimun diharapkan dapat mempengaruhi aspek psikologis, mental dan spiritual pada pasien. Membuat tenang dan menghilangkan kecemasan akan suatu penyakit yang dideritanya. Pemanfaatan sari mentimun sangat baik dan harganya terjangkau.

\section{KESIMPULAN DAN SARAN}

Berdasarkan data yang diperoleh pada penelitian tentang pengaruh sari mentimun terhadap penurunan tekanan darah pada penderita hipertensi di Puskesmas Kedaton Bandar Lampung, dengan jumlah sampel 30 responden dapat disimpulkan bahwa rata-rata tekanan sistole pada penderita hipertensi yang diberikan sari mentimun adalah $14,00 \mathrm{mmHg}$ sedangkan rata - rata tekanan diastole pada penderita hipertensi yang diberikan sari mentimun adalah 10,00 $\mathrm{mmHg}$.

Terdapat pengaruh penurunan tekanan darah sistole dan diastole pada penderita Hipertensi sesudah pemberian sari mentimun dengan $\mathrm{p}$ value untuk sistole adalah $0,001(\mathrm{p}<0,05)$ dan tekanan darah diastole pada penderita hipertensi sesudah pemberian sari mentimun diperoleh $\mathrm{p}$ value $0,01(\mathrm{p}<0,05)$ yang artinya ada pengaruh terhadap penurunan tekanan darah pada penderita hipertensi setelah diberikan sari mentimun.

Berdasarkan hasil penelitian, peneliti ingin memberikan saran kepada Puskesmas Kedaton agar menjadikan terapi herbal (sari mentimun) sebagai upaya alternatif dalam penatalaksanaan pada penderita hipertensi.

Kepada responden diharapkan untuk tetap meminum sari mentimun sebagai pengobatan hipertensi dan menganjurkan keluarga dan saudara yang lain untuk mengikuti pengobatan terapi herbal dengan sari mentimun ini. 


\section{DAFTAR PUSTAKA}

Dinkes Provinsi Lampung (2012). Data 10

Besar Penyakit. Bandar Lampung:

Dinkes Provinsi Lampung

Muniroh, dkk. (2007). Pengaruh Pemberian Jus Buah Belimbing dan Mentimun terhadap Penurunan Tekanan Darah Sistolik dan Diastolik Penderita Hipertensi Di Puskesmas Grati Kabupaten Pasuruan. Journal Fakultas Kesehatan Masyarakat Universitas Airlangga.

Marbun, dkk. (2012). Pengaruh Jus Mentimun (Cucumis Sativus Linn) Terhadap Tekanan Darah Pada Penderita Hipertensi Di Lingkungan Xii Kelurahan Dwikora Kecamatan Medan Helvetia. (diunduh 31 Maret 2016 )

Notoatmodjo, (2012). Metodologi Penelitian Kesehatan. Jakarta: Rineka Cipta

Puskesmas Kedaton, (2016). Profil Puskesmas Kedaton. Bandar Lampung: Puskesmas Kedaton

Suprapto (2014). Menu Ampuh Atasi Hipertensi. Yogyakarta: Notebook

Yekti S \& Ari Wulandari. (2014). Cara Jitu Mengatasi Hipertensi. Yogyakarta: Andi Offset. 
J urnal Aisyah: J urnal Ilmu Kesehatan, 3(1), J uni 2018, - 8

Nur Sefa Arief Hermawan, Nana Novariana 